\title{
From needs analysis to development of a vocational English language curriculum: A practical guide for practitioners
}

\author{
Suat Kaya \\ A ̆̆r İbrahim Çeçen University, Turkey
}

\begin{abstract}
This study was conducted to examine the needs of the students of cabin services program regarding English in order to guide the design of a vocational English language curriculum. The research design used in this study was the concurrent triangulation approach, one of the mixed methods models. This approach can be used when the researcher collects both qualitative and quantitative data at the same time not giving privilege to either approach. It compares the two different data types to find out similarities and differences. There were two groups of participants in this study. The first group was composed of 352 students, enrolled in the Vocational School of Civil Aviation from four universities, who were selected with cluster sampling method, while the second group included 10 instructors working in these universities and four in-service flight attendants. A questionnaire and a semi-structured interview developed by the researcher were utilized to collect data. The quantitative data obtained from the questionnaire were analyzed through descriptive statistics procedures including frequencies, percentages, means and standard deviations, while qualitative data were analyzed through content analysis. Findings revealed that the students needed to develop their speaking and listening skills in order to be successful in their future work settings, although they were least competent in these skills. Based on further findings determined by needs analysis, the study was concluded with a sample guide for practitioners planning to develop a vocational English language curriculum using Hilda Taba's curriculum development model.
\end{abstract}

Keywords: English for specific purposes; Needs analysis; Curriculum development; Cabin crew; Cabin services program

Article History: Submitted 1 December 2020; Revised 19 February 2021; Published online 23 February 2021

\section{Introduction}

The Languages for Specific Purposes (LSP) movement, which is known in English-language teaching circles as English for Specific Purposes (ESP) (Richards, 2001) came into being as a result of the focus on the learner, a revolution in linguistics, and the demands of a Brave New World (Hutchinson \& Waters, 1987). In contrast to the students learning English for general purposes, the ESP students aim to learn English in order to carry out a particular role, such as that of foreign

Address of Corresponding Author

Suat Kaya, PhD, Vocational School of Civil Aviation, Agri Ibrahim Cecen University, Agri, Turkey.

$\triangle$ kayasuat2002@gmail.com

\section{0-0001-6593-3205}

How to cite: Kaya, S. (2021). From needs analysis to development of a vocational English language curriculum: A practical guide for practitioners. Journal of Pedagogical Research, 5(1), 154-171. http://dx.doi.org/10.33902/JPR.2021167471 
student in an English-medium university, flight attendant, mechanic, or doctor (Richards, 2001). "An important principle of ESP approaches to language teaching is that rather than a syllabus reflecting the general structure of English, the purposes for which a learner needs a language should be taken into account while planning an English course" (Richards, 2001, p. 32). As stated by Hutchinson and Waters (1987), ESP is an approach to language teaching in which all decisions with respect to content and method are based on the learners' reasons for learning. Therefore, ESP starts with an analysis of the learners' needs (Brindley, 1989; Richards, 2001), because once the needs of the learners are identified, the instructors can decide on how to help students to learn better and more easily (Dudley-Evans \& St-John, 1998; Hutchinson \& Waters, 1987; Nunan, 1988). "It is probably no exaggeration to say that needs assessment is seen in ESP as the foundation on which all other decisions are, or should be, made" (Belcher, 2006, p. 135), so no ESP courses should be conducted without needs analysis (Kaewpet, 2009).

Needs analysis, "the systematic collection and analysis of all subjective and objective information necessary to define and validate defensible curriculum purposes that satisfy the language learning requirements of students within the context of particular institutions that influence the learning and teaching situation" (Brown, 1995, p. 36), has often been used in foreign language education to find out the particular language skills that the students need and the particular challenges they encounter in the process of improving their language competence (Kikuchi, 2005; Taillefer, 2007; Xiao, 2006). It includes both the study of present needs (Richards, 2001) and potential needs (Chen, 2006; Kaur \& Clarke, 2009).

As stated by Richards (2001), "different types of students have different language needs and what they are taught should be restricted to what they need" (p. 32), and "the problems are unique to specific learners in specific contexts and thus [they] must be carefully delineated and addressed with tailored-to-fit instruction" (Belcher, 2006, p. 135) which can determine the content of any course as well (Richards, 2001). To wrap up, needs analysis gives "learners a voice" (Belcher, 2006, p. 139) in ESP, which is very important for ESP research (Basturkmen \& Lewis, 2002; Benesch, 1996, 1999; Berman \& Cheng, 2001; Evans \& Morrison, 2011a, 2011b; Evans \& Green, 2007; Ferris,1998; Flowerdew \& Miller, 1992; Hyland, 1997; Ivanic, 2006; Leki \& Carson, 1994).

The students at Vocational School of Civil Aviation Department at a public university, where the researcher provides English instruction, are provided with a 3 class hours of English instruction course named as Aviation English for their future careers. However, there is no curriculum developed to satisfy their needs, yet. The aim of this research, in this sense, was to conduct a needs analysis which could be used to guide the design of an English curriculum for these ESP classes of cabin services program. When conducting needs analysis, Hutchinson and Waters (1987) suggest focusing on three subcategories which are (1) necessities referring to the language skills and knowledge students need to have in order to function effectively in a target situation; (2) wants referring to students' perceptions of what needs to be known; and (3) lacks referring to the gap between the students' target proficiency and their existing proficiency. In this respect, the following research questions were formulated to lead the study:

1. What are the contextual issues regarding the necessity and uses of English for students' future work domain?

2. What is the importance of four language skills for students' future work domain after graduation?

3. What are the students' perceptions of their proficiency level in the four language skills?

4. What are the students' perceptions of the difficulties encountered in the four language skills?

5. What kind of specific difficulties do the students encounter in four language skills?

6. What are instructors' and flight attendants' views about the use of English in civil aviation sector?

7. How can the findings determined by needs analysis be used to conclude with a guide for the design of an ESP curriculum for the target students? 


\subsection{Importance of the Study}

This study is significant in some aspects. First of all, "ESP teachers find themselves in a situation where they are expected to produce a course that exactly matches the needs of a group of learners, but are expected to do so with no, or very limited, preparation time" (Jones, 1990, p. 91). In this sense, an ESP practitioner is expected to have five key roles which include being a teacher, a course designer, materials provider, a collaborator, a researcher and an evaluator (Dudley-Evans \& St. John, 1998). This study aims to go beyond needs analysis and it addresses the role of ESP practitioner as a teacher, a researcher, an evaluator and a course designer. In this respect, the findings of this study are expected to guide the designing process of an ESP curriculum for the students in this department. In addition, the procedures applied in the development process can be taken as a guide for the ones planning to develop a vocational English curriculum for different target groups as well.

Second, the studies in literature have mainly collected data from one university or context, which makes them unique cases. With inclusion of four universities, this is one of the unique studies gathering data from more than one university. Therefore, the findings can be thought to be more generalizable.

\subsection{Literature Review}

When the studies conducted in ESP context are examined, it is seen that needs analysis has been conducted for students from various departments including health (e.g., Alfehaid, 2011; Ayas, \& Kırkgöz, 2013; Chia et al., 1999; Gessesse, 2009; Lee, 1998; Mazdayasna, \& Tahririan, 2008; Tasci, 2007), engineering (e.g., Alsamadani, 2017; Clement, \& Murugavel, 2015; Fox, \& Artemeva, 2017; Midoul, 2013; Moyo \& Mann, 2018; Nguyen \& Nguyen, 2017; Ulla \& Winitkun, 2017), tourism (e.g., Buyukyavuz, 2006; Gokce, \& Batman, 2015), Art and Design (Kaur \& Khan, 2010) and business (e.g., Derado, 2015) which arrive at differing needs using the perspectives of the learners and instructors as data (Ali \& Salih, 2013; Arik, 2002; Boran, 1994; Casanave \& Hubbard, 1992; Jenkins et al., 1993; Johns, 1981; Moslemi et al., 2011). This literature review shows that students' need for language differ depending on the department; let alone even the studies conducted for the same target students yielded different results. These varieties can be taken as a prosperity of ESP field as they point to the uniqueness of the students' needs, which is actually the starting point of ESP curricula.

The research studies conducted for the students at the civil aviation department have been quite limited up to now. Especially, the literature, accessible to the researcher, lacks studies conducted for the students of cabin services program. Aviation English refers to "the language used by pilots, air traffic controllers, and other personnel associated with the aviation industry" (Moder, 2013, p. 227). However, Wang (2007) argues that Aviation English is not

...restricted to controller and pilot communications, [it] can also include the use of English relating to any other aspect of aviation: the language needed by pilots for briefings, announcements, and flight deck communication; language used by maintenance technicians, flight attendants, dispatchers, or managers and officials within the aviation industry." (p. 122).

Although the term includes "the language of airline mechanics, flight attendants, or ground service personnel, most research and teaching focus on the more specialized communication between pilots and air traffic controllers, often called radiotelephony" (Moder, 2013, p. 227). To illustrate, Sänne (1999), Nevile (2004), and Wyss-Bühlmann (2005) investigated the work-related contexts of controllers and the pilots; and provided detailed descriptions of the contexts (as cited in Moder, 2013). Likewise, Sullivan and Girginier (2002) focused on the use of discourse analysis in order to design materials for an ESP program in a Civil Aviation School in Turkey. The participants were Turkish controllers and pilots working at Ataturk International Airport. Interviews, observations and questionnaires were utilized to collect data. Depending on the findings, they designed some activities intended to focus on the practice of read backs and the 
pronunciation of numbers. These materials were also intended to solve miscommunication problems and improve comprehension among the parties.

What is to add, there are few studies focusing on other stakeholders in aviation sector. These studies have focused on just one dimension of ESP curriculum for Aviation English. Wang (2007), for example, focused on "aviation English curriculum development in the Chinese context" (p. 121). The researcher briefly mentioned the problems related to Aviation English including, for example, the negative influences of Grammar translation method which assigned a passive role to the learners. He/she concluded with an approach highlighting "phonetic and semantic contrasts" in order to teach vocabulary and pronunciation of Aviation English. In another study, Cutting (2011) elaborated on the English needs for ground staff at European airports. The aim was to develop some materials focusing on the basic English language patterns or features for the staff like bus drivers, security guards, catering staff and ground handlers. For this aim, she conducted observations to examine dialogues taking place between these participants. She concluded with some dialogues necessary for different groups of learners.

\section{Method}

\subsection{Research Design}

The research design used in this study is the concurrent triangulation approach, which is one of the mixed methods models. This approach can be used when "the researcher collects both quantitative and qualitative data concurrently and then compares the two databases to determine if there is convergence, differences, or some combination" (Creswell, 2009, p. 213). To mention some characteristics of this approach, the weight is equal between the two data types; hence one type of data can be transformed into the other in order to compare the results more easily; and these data are mixed in the discussion sections (Creswell, 2009). In this study, a questionnaire and a semi-structured interview were utilized. The qualitative data obtained from interviews were used to compare the quantitative results gained from the questionnaire in order to arrive at "wellvalidated and substantiated findings" (Creswell, 2009, p. 213-214).

\subsection{Participants}

There were two groups of participants in this study. The first group included the students enrolled in Vocational School of Civil Aviation from four universities, while the second group included the instructors working at those universities and in-service flight attendants. As stated by Gall et al. (2003), sample size is important for generalizability of research findings. At least 100 participants are accepted to be enough for descriptive studies and the researchers can try to reach the biggest sample size they can depending on the time and energy they have (Fraenkel et al., 2012), which can increase reliability of the research (Cohen et al., 2007). For this study, 352 students who were selected from four universities through cluster sampling method constituted the sample. Demographic characteristics of the students are summarized in Table 1.

Table 1

Demographic characteristics of the students

\begin{tabular}{lcccc}
\hline & Categories & $f$ & $\%$ & $M$ \\
\hline Gender & Male & 164 & 46.6 & \\
& Female & 188 & 53.4 & \\
\hline Age & & & & 19.5 \\
\hline Program & Cabin Services & 352 & 100 & \\
\hline Grade Level & First & 192 & 54.5 & \\
& Second & 160 & 45.5 & \\
\hline
\end{tabular}

As seen in the table, the sample included 188 females $(53.4 \%)$ and 164 males $(46.6 \%)$. The average age of the participants was found to be 19.5. All participants were students at the cabin 
services program. Last, 192 students (54.5\%) were at the first, while 160 (45.5\%) were at the second grade level.

On the other hand, the second group, which included 10 instructors working at those universities, was selected on the basis of willingness. There were six females (i2, i3, i6, i8, i9, i10) and four males (i1, i4, i5, i7) in the sample of instructors. The average age was found to be 29.7, while they had 8.5 years of experience in teaching on average. Meanwhile, there were two female (FA3, FA4) and two male flight attendants (FA1, FA2). The average age was found to be 32.6, while they had 10 years of working experience on average.

\subsection{Data Collection Tools}

The researcher developed a semi-structured interview and a questionnaire to collect data. During the development process of the questionnaire, the related literature (Boran, 1994; Gessesse, 2009; Richards, 2001) was examined in detail. The items selected from the related literature were collected in a pool, and then the most suitable items were chosen for this study. 47 items were selected at the beginning, then they were sent to experts from English language teaching department so as to take views in order to measure the questionnaire's content validity. As a result of expert opinions, necessary changes were applied to the questionnaire in terms of its shape and wording of the items. For example, the first draft of the questionnaire consisted of 47 items; however, some items were combined and deleted or restated according to expert opinions. In addition, the format of the questionnaire was changed and some instructions were reworded based on these opinions. Afterwards, five students were requested to read the questionnaire to examine the questionnaire's face-related validity. The results indicated that the items were understood as intended. At the end, the questionnaire was pilot tested with 57 students to measure its reliability, which yielded .91 Cronbach's alpha value.

At the end of all these procedures, the questionnaire consisted of three sections; the first section included items about demographic characteristics of the students, the second one was composed of items regarding contextual issues of the use of English, and the third section had 41 items about students' needs including their necessities, wants and lacks. The third section of the questionnaire had seven sub-sections which were named as importance of four language skills for students' future work domain, students' proficiency levels in four language skills, frequency of difficulties experienced in four language skills, students' perceptions of their speaking difficulties, students' perceptions of their listening difficulties, students' perceptions of their reading difficulties and students' perceptions of their writing difficulties. All subsections except for contextual issues were modelled on a five-point Likert scale. In these scales, depending on the data, the students were asked to rate the level of frequency, importance or competence by rating each item on the fivepoint scales based on the data such as "1- never, 2- rarely, 3- sometimes, 4- often, 5- always"; "1very incompetent, 2- incompetent, 3- moderately competent, 4- competent, 5- very competent"; and "1- very unimportant, 2- unimportant, 3- moderately important, 4- important, 5- very important".

On the other hand, the semi-structured interview had three parts. In the first part, there were items about their demographic characteristics, while the second part included similar items about the contextual issues regarding the necessity and uses of English for students' future work domain like the second section of the student questionnaire. The last part, on the other hand, included four open-ended questions which were asked to examine their views about the necessity of English for these students' future work domain, the importance of specific language skills for the students' future work domain, specific language patterns, and the types of duties in students' future work domain.

\subsection{Data Collection Process}

The Ethics Committee/Board approval for this study was obtained from Scientific Research Ethics Committee of Agri Ibrahim Cecen University in 08/09/2020 numbered 113. No ethical considerations were violated in this study. Upon the approval, data collection process began with 
quantitative data collection from the students and continued with qualitative data collection from other participants. The students at the university where the researcher worked completed the questionnaire during a course, while the students from other universities completed it via an online form of the questionnaire. The same procedure worked in the process of gathering qualitative data. To this connection, the instructors working in the same university as the researcher were interviewed in the researcher's room, and each interview lasted for an average of 32 minutes. On the other hand, the instructors from other universities and flight attendants were interviewed through an online communication system.

\subsection{Data Analysis}

As aforementioned, both qualitative and quantitative data were collected. The quantitative data obtained through the questionnaire were analyzed using descriptive statistics procedures including percentages, frequencies, means and standard deviations. On the other hand, content analysis technique was utilized to analyze the qualitative data. Further, the results of qualitative data analysis were transformed into quantitative data using percentages and frequencies in order to compare the two types of data more conveniently. In order to measure the reliability of the qualitative data analysis, one of the interviews was selected randomly and it was sent to two independent experts in qualitative research methodologies in order to measure the intercoder reliability. The intercoder reliability was measured by the formula suggested by Miles and Huberman (1994, p. 64) and it yielded a value of $84 \%$ which satisfied reliability of qualitative data analysis.

\section{Results}

As data were collected from different participants, the findings have been reported under different subheadings. These findings have been compared and converged in the discussion part.

\subsection{Quantitative Findings Based on the Perceptions of the Students}

The findings with respect to the first research question, which was asked to find out the contextual issues regarding the necessity and uses of English for students' future work domain, are presented in Table 2.

Table 2

Students' views about contextual issues regarding the necessity and uses English for their future work domain

\begin{tabular}{llcc}
\hline & Categories & $f$ & $\%$ \\
\hline Necessity of English in & Yes & 352 & 100 \\
Aviation Sector & No & 0 & 0 \\
\hline The aim for & & & \\
learning English & For future career & 298 & 84.7 \\
& For future education & 54 & 15.3 \\
\hline Future job settings & Airport & 338 & 96 \\
& Business office & 2 & .6 \\
& Travel agency & 10 & 2.8 \\
& Hotel, motel, café, restaurant & 1 & .3 \\
& School & 1 & .3 \\
\hline Future Interlocutors & Native English & 12 & 3.4 \\
& Non-native English & 20 & 5.7 \\
& Both & 320 & 90.9 \\
\hline Channel of communication & Face to face conversations & 262 & 74.4 \\
in their future careers & Phone conversations & 54 & 15.3 \\
& Radio contact & 36 & 10.3 \\
\hline
\end{tabular}


As seen in the table, all students $(n=352)$ reported that English was necessary in aviation sector, and a great majority of them (84.7\%) aimed to learn English for their future career, while some $(15.3 \%)$ aimed to learn English for their future education. With respect to their future job settings, the airport was reported to be their most likely job setting (96\%), while travel agency $(2.8 \%)$, business office $(.6 \%)$, hotel, motel, café, restaurant $(.3 \%)$ and school $(.3 \%)$ were also reported to be among their other likely job settings in the future. Regarding their future interlocutors, a vast majority $(90.9 \%)$ reported that they would speak to both native and non-native speakers of English. Lastly, according to the findings with respect to the channel of communication in their future careers, face to face conversations (74.4\%) were ranked as the mostly used channel of communication, while phone conversations $(15.3 \%)$, and radio contact $(10.3 \%)$ were counted as others. These findings indicate that English is vital for this sample of students who learn it for their future career. That is because, they will have to work mainly in an airport where there will be passengers using both native and non-native English.

Table 3 presents the findings with respect to the importance of four language skills for students' future work domain after graduation. As seen in the table, the most important language skill was reported to be speaking skills $(M=4.79, S D=.64)$, which was followed by listening skills $(M=4.52$, $S D=.71)$. On the other hand, writing $(M=3.16, S D=1.5)$, and reading skills $(M=3.12, S D=1.5)$ were reported to have less importance for their future work domain.

Table 3

Students' perceptions of the importance of the four language skills for their future work domain

\begin{tabular}{lcccccccccccc}
\hline & \multicolumn{2}{c}{$\begin{array}{c}\text { Very } \\
\text { Important }\end{array}$} & \multicolumn{3}{c}{ Important } & \multicolumn{2}{c}{$\begin{array}{c}\text { Moderately } \\
\text { Important }\end{array}$} & \multicolumn{1}{c}{ Unimportant } & \multicolumn{3}{c}{$\begin{array}{l}\text { Very } \\
\text { Unimportant }\end{array}$} \\
\hline Skills & $f$ & $\%$ & $f$ & $\%$ & $f$ & $\%$ & $f$ & $\%$ & $f$ & $\%$ & $M$ & $S D$ \\
\hline 1.Reading & 0 & 0 & 6 & 1.7 & 30 & 8.5 & 106 & 30.1 & 210 & 59.7 & 3.12 & 1.5 \\
\hline 2. Writing & 6 & 1.7 & 134 & 38.1 & 46 & 13.1 & 42 & 11.9 & 124 & 35.2 & 3.16 & 1.5 \\
\hline 3. Speaking & 156 & 44.3 & 72 & 20.5 & 72 & 20.5 & 8 & 2.3 & 44 & 12.5 & 4.79 & .64 \\
\hline 4. Listening & 106 & 30.1 & 122 & 34.7 & 72 & 20.5 & 12 & 3.4 & 40 & 11.4 & 4.52 & .71 \\
\hline
\end{tabular}

The findings regarding the students' proficiency levels in four language skills are presented in Table 4. According to these findings, students were most competent in reading skills $(M=3.30$, $S D=.99)$, while they were least competent in speaking skills $(\mathrm{M}=2.34, \mathrm{SD}=1.16)$.

Table 4

Students' perceptions of their proficiency level in the four language skills

\begin{tabular}{lcccccccccccc}
\hline & \multicolumn{2}{c}{$\begin{array}{c}\text { Very } \\
\text { Competent }\end{array}$} & \multicolumn{2}{c}{ Competent } & \multicolumn{2}{c}{$\begin{array}{c}\text { Moderately } \\
\text { Competent }\end{array}$} & \multicolumn{1}{c}{ Incompetent } & \multicolumn{2}{c}{$\begin{array}{l}\text { Very } \\
\text { Incompetent }\end{array}$} \\
\hline Skills & $f$ & $\%$ & $f$ & $\%$ & $f$ & $\%$ & $f$ & $\%$ & $f$ & $\%$ & $M$ & $S D$ \\
\hline 1. Reading & 14 & 4 & 58 & 16.5 & 124 & 35.2 & 120 & 34.1 & 36 & 10.2 & 3.30 & .99 \\
\hline 2. Writing & 26 & 7.4 & 78 & 22.2 & 156 & 44.3 & 62 & 17.6 & 30 & 8.5 & 2.98 & 1.02 \\
\hline 3.Speaking & 20 & 5.7 & 40 & 11.4 & 76 & 21.6 & 120 & 34.1 & 96 & 27.3 & 2.34 & 1.16 \\
\hline 4.Listening & 22 & 6.3 & 38 & 10.8 & 98 & 27.8 & 166 & 47.2 & 28 & 8 & 2.60 & .99 \\
\hline
\end{tabular}

As can be seen in Table 3 and 4, although proficiency in speaking and listening skills is more important for these students, they reported them as the areas in which they are least competent.

Table 5 presents findings with respect to the frequency of the difficulties encountered by the students in four language skills. The table indicated that students had difficulty in speaking skills most frequently $(M=4.06, S D=1.08)$, while they encountered difficulties in reading skills least frequently $(M=2.77, S D=1.08)$. These findings support the preceding findings presented and reported through Table 3 and 4. 
Table 5

The frequency of difficulties encountered in four language skills

\begin{tabular}{lcccccccccccc}
\hline & \multicolumn{2}{c}{ Always } & \multicolumn{2}{c}{ Often } & \multicolumn{2}{c}{ Sometimes } & \multicolumn{2}{c}{ Seldom } & \multicolumn{2}{c}{ Never } \\
\hline Skills & $f$ & $\%$ & $f$ & $\%$ & $f$ & $\%$ & $f$ & $\%$ & $f$ & $\%$ & $M$ & $S D$ \\
\hline 1. Reading & 28 & 8 & 54 & 15.3 & 11 & 33 & 116 & 33 & 38 & 10.8 & 2.77 & 1.08 \\
\hline 2. Writing & 32 & 9.1 & 102 & 29 & 120 & 34.1 & 68 & 19.3 & 30 & 8.5 & 3.11 & 1.09 \\
\hline 3. Speaking & 166 & 47.2 & 84 & 23.9 & 70 & 19.9 & 22 & 6.3 & 10 & 2.8 & 4.06 & 1.08 \\
\hline 4. Listening & 40 & 11.4 & 204 & 58 & 80 & 22.7 & 16 & 4.5 & 12 & 3.4 & 3.69 & .86 \\
\hline
\end{tabular}

After the above analyses, particular difficulties encountered in four language skills were investigated. While reporting these findings, the number and percentage of the students who reported the frequency of a difficulty as "always or often" were summed up, likewise the number and percentage of the participants who reported the frequency as "seldom or never" were summed up.

Table 6 presents the findings regarding the particular difficulties the students encounter in speaking skills. As seen in this table, the students had difficulty in "wording what they wanted to say quickly enough" most frequently $(M=4.06, S D=1.08)$, while they had difficulty in "knowing how to say something in English" least frequently $(M=2.77, S D=.83)$. Still, it is possible to state that the students had difficulty in almost all items regarding speaking skills.

Table 6

Students' perceptions of their speaking difficulties

\begin{tabular}{|c|c|c|c|c|c|c|c|c|c|c|c|c|}
\hline & \multicolumn{2}{|c|}{ Always } & \multicolumn{2}{|c|}{ Often } & \multicolumn{2}{|c|}{ Sometimes } & \multicolumn{2}{|c|}{ Seldom } & \multicolumn{2}{|c|}{ Never } & & \\
\hline $\begin{array}{l}\text { How often do the following } \\
\text { happen to you? }\end{array}$ & $f$ & $\%$ & $f$ & $\%$ & $f$ & $\%$ & $f$ & $\%$ & $f$ & $\%$ & $M$ & $S D$ \\
\hline $\begin{array}{l}\text { 1. Have difficulty giving oral } \\
\text { presentations. }\end{array}$ & 72 & 20.5 & 98 & 27.8 & 156 & 44.3 & 12 & 3.4 & 14 & 4 & 3.57 & .98 \\
\hline $\begin{array}{l}\text { 2. Have trouble wording } \\
\text { what you want to say } \\
\text { quickly enough. }\end{array}$ & 96 & 27.3 & 154 & 43.8 & 80 & 22.7 & 14 & 4 & 8 & 2.3 & 3.90 & .93 \\
\hline $\begin{array}{l}\text { 3. Worry about saying } \\
\text { something in case you make } \\
\text { a mistake in your English. }\end{array}$ & 120 & 34.1 & 126 & 35.8 & 62 & 17.6 & 26 & 7.4 & 18 & 5.1 & 3.86 & 1.12 \\
\hline $\begin{array}{l}\text { 4. Not know how to say } \\
\text { something in English. }\end{array}$ & 134 & 38.1 & 46 & 13.1 & 152 & 43.2 & 12 & 3.4 & 8 & 2.3 & 2.77 & .83 \\
\hline $\begin{array}{l}\text { 5. Not know the best way to } \\
\text { say something in English. }\end{array}$ & 74 & 21 & 126 & 35.8 & 74 & 21 & 64 & 18.2 & 14 & 4 & 3.28 & 1.11 \\
\hline $\begin{array}{l}\text { 6. Have difficulty with your } \\
\text { pronunciation of words. }\end{array}$ & 100 & 28.4 & 118 & 33.5 & 58 & 16.5 & 56 & 15.9 & 20 & 5.7 & 3.09 & 1.15 \\
\hline $\begin{array}{l}\text { 7. Have difficulty } \\
\text { remembering the English } \\
\text { equivalent of the word I } \\
\text { want to say. }\end{array}$ & 72 & 20.5 & 158 & 44.9 & 68 & 19.3 & 8 & 2.3 & 46 & 13.1 & 3.23 & .98 \\
\hline
\end{tabular}

The findings with respect to the particular difficulties the students encountered in listening skills are presented in Table 7. As seen in the table, the students had difficulty in "understanding fast conversations" most frequently $(M=4.05, S D=1.02)$, while they had difficulty in "remembering the Turkish equivalent of the words they heard" least frequently $(M=3.32, S D=.78)$. These findings are similar to the preceding table indicating that the students had difficulty in almost all items regarding listening skills. 
Table 7

Students' perceptions of their listening difficulties

\begin{tabular}{lccccccccccccc}
\hline & Always & \multicolumn{1}{c}{ Often } & \multicolumn{2}{c}{ Sometimes } & \multicolumn{2}{c}{ Seldom } & Never & & \\
\hline I have trouble in... & $f$ & $\%$ & $f$ & $\%$ & $f$ & $\%$ & $f$ & $\%$ & $f$ & $\%$ & $M$ & $S D$ \\
\hline $\begin{array}{l}\text { 1.understanding lengthy } \\
\text { descriptions of English. }\end{array}$ & 48 & 13.6 & 148 & 42 & 124 & 35.2 & 24 & 6.8 & 8 & 2.3 & 3.58 & .89 \\
\hline $\begin{array}{l}\text { 2.understanding spoken } \\
\text { instructions. }\end{array}$ & 42 & 11.9 & 114 & 32.4 & 130 & 36.9 & 58 & 16.5 & 8 & 2.3 & 3.35 & .97 \\
\hline $\begin{array}{l}\text { 3.understanding informal } \\
\text { English. }\end{array}$ & 70 & 19.9 & 160 & 45.5 & 76 & 21.6 & 38 & 10.8 & 8 & 2.3 & 3.70 & .98 \\
\hline $\begin{array}{l}\text { 4. understanding the subject } \\
\text { matter of a talk. }\end{array}$ & 80 & 22.7 & 86 & 24.4 & 114 & 32.4 & 72 & 20.5 & 0 & 0 & 3.49 & 1.08 \\
\hline $\begin{array}{l}\text { 5.understanding fast } \\
\text { conversations. }\end{array}$ & 136 & 38.6 & 144 & 40.9 & 32 & 9.1 & 32 & 9.1 & 8 & 2.3 & 4.05 & 1.02 \\
\hline $\begin{array}{l}\text { 6. remembering the Turkish } \\
\text { equivalent of the words I hear. }\end{array}$ & 24 & 6.8 & 110 & 31.3 & 174 & 49.4 & 44 & 12.5 & 0 & 0 & 3.32 & .78 \\
\hline $\begin{array}{l}\text { 7. understanding the grammar } \\
\text { people use. }\end{array}$ & 62 & 17.6 & 76 & 21.6 & 158 & 44.9 & 44 & 12.5 & 12 & 3.4 & 3.38 & 1.02 \\
\hline $\begin{array}{l}\text { 8.understanding conversations } \\
\text { in different accents. }\end{array}$ & 104 & 29.5 & 124 & 35.2 & 104 & 29.5 & 12 & 3.4 & 8 & 2.3 & 3.86 & .96 \\
\hline
\end{tabular}

Table 8 presents the findings related to the students' perceptions of the reading difficulties they encountered. As seen in the table, the students had difficulty in "scanning" $(M=3.47, S D=1.06)$ and "understanding a text due to lack of vocabulary knowledge" most frequently $(M=3.47, S D=1.09)$, while they had difficulty in "understanding a text due to lack of grammar knowledge" least frequently $(M=3.11, S D=1.05)$.

Table 8

Students' perceptions of their reading difficulties

\begin{tabular}{|c|c|c|c|c|c|c|c|c|c|c|c|c|}
\hline & \multicolumn{2}{|c|}{ Always } & \multicolumn{2}{|c|}{ Often } & \multicolumn{2}{|c|}{ Sometimes } & \multicolumn{2}{|c|}{ Seldom } & \multicolumn{2}{|c|}{ Never } & \multirow[b]{2}{*}{$M$} & \multirow[b]{2}{*}{$S D$} \\
\hline I have trouble in ... & $f$ & $\%$ & $f$ & $\%$ & $f$ & $\%$ & $f$ & $\%$ & $f$ & $\%$ & & \\
\hline $\begin{array}{l}\text { 1.understanding the main } \\
\text { points of text. }\end{array}$ & 50 & 14.2 & 98 & 27.8 & 126 & 35.8 & 64 & 18.2 & 14 & 4 & 3.30 & 1.05 \\
\hline 2. skimming. & 78 & 22.2 & 78 & 22.2 & 136 & 38.6 & 40 & 11.4 & 20 & 5.7 & 3.44 & 1.12 \\
\hline $\begin{array}{l}\text { 3. guessing unknown words in } \\
\text { a text. }\end{array}$ & 46 & 13.1 & 94 & 26.7 & 142 & 40.3 & 70 & 19.9 & 0 & 0 & 3.33 & .94 \\
\hline 4. scanning. & 74 & 21 & 90 & 25.6 & 124 & 35.2 & 56 & 15.9 & 8 & 2.3 & 3.47 & 1.06 \\
\hline $\begin{array}{l}\text { 5.understanding a text due to } \\
\text { lack of grammar knowledge. }\end{array}$ & 50 & 14.2 & 54 & 15.3 & 146 & 41.5 & 90 & 25.6 & 12 & 3.4 & 3.11 & 1.05 \\
\hline $\begin{array}{l}\text { 6.understanding a text due to } \\
\text { lack of vocabulary knowledge. }\end{array}$ & 66 & 18.8 & 118 & 33.5 & 98 & 27.8 & 56 & 15.9 & 14 & 4 & 3.47 & 1.09 \\
\hline $\begin{array}{l}\text { 7.general reading } \\
\text { comprehension. }\end{array}$ & 32 & 9.1 & 100 & 28.4 & 124 & 35.2 & 90 & 25.6 & 6 & 1.7 & 3.18 & .97 \\
\hline
\end{tabular}

Table 9 shows the findings regarding students' perceptions of the writing difficulties they encountered. As seen, the students had difficulty in "expressing ideas appropriately" most frequently $(M=3.48, S D=1.17)$, while they had difficulty in "using appropriate vocabulary" least frequently $(M=3.22, S D=.93)$. 
Table 9

Students' perceptions of their writing difficulties

\begin{tabular}{|c|c|c|c|c|c|c|c|c|c|c|c|c|}
\hline & \multicolumn{2}{|c|}{ Always } & \multicolumn{2}{|c|}{ Often } & \multicolumn{2}{|c|}{ Sometimes } & \multicolumn{2}{|c|}{ Seldom } & \multicolumn{2}{|c|}{ Never } & \multirow[b]{2}{*}{$M$} & \multirow[b]{2}{*}{$S D$} \\
\hline I have trouble in... & $f$ & $\%$ & $f$ & $\%$ & $f$ & $\%$ & $f$ & $\%$ & $f$ & $\%$ & & \\
\hline $\begin{array}{l}\text { 1.using correct punctuation } \\
\text { and spelling. }\end{array}$ & 48 & 13.6 & 102 & 29 & 126 & 35.8 & 52 & 14.8 & 24 & 6.8 & 3.28 & 1.09 \\
\hline 2.structuring sentences. & 30 & 8.5 & 126 & 35.8 & 124 & 35.2 & 60 & 17 & 12 & 3.4 & 3.29 & .96 \\
\hline $\begin{array}{l}\text { 3.using appropriate } \\
\text { vocabulary. }\end{array}$ & 24 & 6.8 & 116 & 33 & 138 & 39.2 & 62 & 17.6 & 12 & 3.4 & 3.22 & .93 \\
\hline 4.organizing paragraphs. & 76 & 21.6 & 120 & 34.1 & 74 & 21 & 62 & 17.6 & 20 & 5.7 & 3.48 & 1.17 \\
\hline $\begin{array}{l}\text { 5.expressing ideas } \\
\text { appropriately. }\end{array}$ & 58 & 16.5 & 140 & 39.8 & 102 & 29 & 46 & 13.1 & 6 & 1.7 & 3.56 & .97 \\
\hline 6. developing ideas. & 62 & 17.6 & 76 & 21.6 & 128 & 36.4 & 60 & 17 & 26 & 7.4 & 3.25 & 1.15 \\
\hline $\begin{array}{l}\text { 7.expressing what I want to } \\
\text { say clearly. }\end{array}$ & 44 & 12.5 & 128 & 36.4 & 110 & 31.3 & 40 & 11.4 & 30 & 8.5 & 3.33 & 1.10 \\
\hline
\end{tabular}

Based on the findings presented in Table 8 and 9, it is possible to state that the students have difficulty in reading and writing skills as well, however they do not encounter those difficulties as frequently as the ones encountered in listening and speaking skills.

\subsection{Qualitative Findings Based on the Views of the Instructors and Flight Attendants}

As aforementioned, a parallel form like students' was used to collect data about contextual issues regarding the necessity and uses of English for students' future work domain. Findings revealed that there was consensus among instructors about the necessity of English for the students' future job settings which was reported to be airports $(f=14)$, future linguistic settings which included Turkey, an English speaking country and a non-English speaking country $(f=14)$ and future interlocutors who included both native and nonnative speakers of English $(f=14)$. Regarding channel of communication, however, different ideas were shared. They pointed to face to face conversations and radio contacts $(f=11)$ and phone conversations $(f=3)$. In this sense, it is possible state these findings support the findings regarding students' perceptions.

Table 10 summarizes the themes and their corresponding codes with respect to the views of the instructors and the flight attendant. The findings of content analysis revealed three themes which were called as "skill priority", "content" and "objectives. In addition, the second theme content yielded two sub-themes called "terminology" and "career stages". As seen in the table, the instructors indicated that listening and speaking skills should be focused on most $(f=14)$, while reading and writing were reported to have the second priority. One instructor (i7) even compared the importance and/or priority of listening and speaking skills suggesting that:

The students will encounter many native and non-native speakers of English in their job especially during international flights. Therefore, they will frequently make face to face conversations. No matter what, they have to first understand what people are talking about or what they ask for. Otherwise, they cannot respond to these people as expected. In other words, speaking phase comes after understanding what is told or asked. I mean listening comprehension comes first.

These lines draw attention to the vitality of English in aviation sector, the need for face to face conversation which necessitates competence in speaking and listening skills. 
Table 10

The themes and the corresponding codes for the use of English in Civil Aviation Department

\begin{tabular}{|c|c|c|c|c|}
\hline Themes & Sub-themes & Codes & $f$ & $\%$ \\
\hline \multirow[t]{2}{*}{ 1. Skill priority } & & 1.1. Listening \& speaking as first priority & 14 & 100 \\
\hline & & 1.2. Reading \& writing as second priority & 11 & 78.6 \\
\hline \multirow[t]{19}{*}{ 2. Content } & 2.1. Terminology & 2.1.1. Aviation terminology & 10 & 71.4 \\
\hline & & 2.1.2. Foods \& drinks & 8 & 57.1 \\
\hline & & 2.1.3. Time & 7 & 50 \\
\hline & & 2.1.4. Prices & 4 & 28.6 \\
\hline & & 2.1.5. Duty-free items & 5 & 35.7 \\
\hline & & 2.1.6. Emergency cases & 5 & 35.7 \\
\hline & & 2.1.7. Emergency equipment & 4 & 28.6 \\
\hline & & 2.1.8. Forbidden objects & 4 & 28.6 \\
\hline & 2.2. Career stages & 2.2.1. Duties in reservations & 3 & 21.5 \\
\hline & & 2.2.2. Duties in ground operations & 4 & 28.6 \\
\hline & & 2.2.3. Duties in baggage & 6 & 42.9 \\
\hline & & 2.2.4. Duties in ticketing & 4 & 28.6 \\
\hline & & 2.2.5 Duties in gate check-in & 3 & 21.5 \\
\hline & & 2.2.6. Duties in the ramp & 4 & 28.6 \\
\hline & & 2.2.7. Occurrences before the flight & 8 & 57.1 \\
\hline & & 2.2.8. Occurrences during the flight & 8 & 57.1 \\
\hline & & 2.2.9. Health issues & 10 & 71.4 \\
\hline & & 2.2.10. Food service & 12 & 85.4 \\
\hline & & 2.2.11. After-flight duties & 8 & 57.1 \\
\hline \multirow[t]{8}{*}{ 3. Objectives } & & 3.1. Asking/answering questions & 10 & 71.4 \\
\hline & & 3.2. Accepting/refusing requests & 8 & 57.1 \\
\hline & & 3.3. Apologizing & 4 & 28.6 \\
\hline & & 3.4. Making requests & 6 & 42.9 \\
\hline & & 3.5. Making explanations & 7 & 50 \\
\hline & & 3.6. Making suggestions & 6 & 42.9 \\
\hline & & 3.7. Giving advice & 5 & 35.7 \\
\hline & & 3.8. Offering help & 3 & 21.5 \\
\hline
\end{tabular}

A flight attendant (FA4) stated that:

Before I became a flight attendant, I started in reservations. Afterwards, I moved to the airport. Then I started to work in ground operations, baggage, ticketing, gate check-in, and the ramp. The last step was to fly. Therefore, the terminology related to all these duties should be learned by the candidates.

In these lines, she elaborated on the terminology issue and explained her steps to be a flight attendant, which indicated different duties and also the stages of their career path.

Another flight attendant (FA1) pointed to their duties, responsibilities and the unexpected events before the flight and reported that:

Before the flight, we [flight attendants] introduce ourselves at the briefing before the flight. After that we talk about and actually discuss everything including flight details, aircraft configuration, emergency equipment, and share our duties. In addition, we have to search for any dangerous or forbidden objects on board although the time is limited [...] One day, there was a blind passenger on board, so I had to take care of him by accompanying him to his seat. We must be ready for anything.

In response to the necessary content question, a flight attendant (FA2) shared one of his experiences during the flight stating that:

Actually, I can answer this questions with many examples from my experiences. First of all, the students as future flight attendants should learn about possible problems that can be encountered on board. For example, there is sometimes delay after boarding. If this happens, the passengers normally wonder about it and ask a lot of questions. We have to inform many of these passengers. 
We request to serve them food and drinks if they wish. The important point here is to be quite polite while asking and answering questions.

As another possible problem, a flight attendant (FA4) pointed to her experience with different problems encountered on board and reported that:

Sometimes, there are some ill passengers in the plane. The flight attendants have to deal with their problems as well. We give them suggestions like doctors or at least consultants. We try to calm them down in these cases. Likewise, in case of a turbulence, the passengers need to be relieved, so give them advices. Sometimes we encounter some angry passengers, so we try our best to calm them down as well. Actually, we act like real problem solvers and I sometimes feel like a suggestion provider...

Another flight attendant mentioned her duties during the flights, specifically the international flights and reported that:

One of our best-known duty is to serve foods and drinks. Most of the passengers wait for this service. We need to be very patient during this activity, because we encounter various requests from the passengers. Regarding international flights, we turn into saleswoman, because sell duty-free items. This is a very tiring job and I hate it. They ask many questions about the items including their quality, price, they even make bargains. (FA3)

Some of the most detailed views of the flight attendants presented directly above can be taken as reference points while developing and organizing the content of an ESP curriculum for aviation as they refer to valuable conversation topics most likely to occur between a flight attendant and a passenger. They can also be used to formulate the objectives of the curriculum. That is because, these direct quotations can be turned into objectives like "accepting/refusing/making requests, making explanations, asking/answering questions, making suggestions, giving advice, offering help etc."

\section{Discussion and Conclusion}

The aim of this research was to arrive at some insights which could guide the design of a curriculum for the ESP classes of cabin services program. The findings and the corresponding discussion with respect to the related research questions are presented below.

To start with contextual issues regarding the necessity and uses of English for students' future work domain, the participants agree that English is necessary for aviation sector. This finding is echoed by the studies of Boran (1994), Diken (2006), Ulla and Winitkun (2017) who used different target students in their studies. This finding shows the unique needs of particular students. The second finding was that the airports will be their most likely job setting. To this connection, the sentence patterns and vocabulary used in an airport setting can be part of an ESP curriculum designed specifically for the students of cabin services.

With respect to the channel of communication in their future careers, face to face conversations were ranked as the mostly used channel of communication as found by Boran (1994) and Diken (2006), while phone conversations and radio contact were counted as other ways of communication. To this connection, it is possible to state that the students will need to establish communication frequently while working. Considering the international passengers, they will be expected to communicate in English. Hence, students need to be provided with speaking activities more frequently than other skills. This finding was consolidated with the perceptions of the students, the views of the instructors and the flight attendants about the most important language skills for their job as well, because the findings indicated that listening and speaking skills were the most important language skills for their future job settings. The literature, on this issue, points to different language skills for different participants. To illustrate, the findings of the studies conducted by Boran, 1994, Gokce and Batman (2015), Kaur and Khan (2010), Nguyen and Nguyen, (2017) pointed to the same skills as important ones for the target students in their studies, while speaking and writing were found to be the skills that engineering students needed to develop most in the study of Midoul (2013). Arik (2002) reported that priority should be given to reading skills, 
while Mazdayasna and Tahririan (2008) and Buyukyavuz (2006) found out that reading comprehension, followed by listening, speaking and writing were the most important skills needed for their target students. Ulla and Winitkun (2017) and Diken (2006) emphasized the importance of speaking skills. On the other hand, in the sudy of Alsamadani (2017), students pointed to the importance of reading and writing skills, while the teachers regarded reading and listening skills as the most important skills. Likewise, Gessesse (2009) found that students proposed speaking and reading as the most important skills to develop, while the teachers recommended speaking and writing as the most important skills. In contrast to these studies which lacked a consensus among the participants indicating the importance of different language skills for the same target groups, all participants included in this study pointed to the same language skills, which supports the reliability of this study.

Afterwards, the students' proficiency levels in the four language skills were investigated through students' perceptions. The findings of this study, in line with the study of Boran (1994), indicated that the students were least competent in speaking and listening skills although they were expected to be more competent in these skills. On the other hand, Alsamadani (2017) found that the students were least competent in speaking and writing skills.

Likewise, as a cross-validating finding, the students reported that they encountered difficulty in speaking skills most frequently, which was followed by listening skills. Therefore, more emphasis should be paid on speaking and listening skills; otherwise, students could have communication problems in their future work settings, or worse they might not even manage to attain a job.

After these analyses, the specific difficulties or problematic subskills encountered in specific language skills were investigated. The findings regarding the difficulties encountered in speaking skills indicated that the students "had difficulty in giving oral presentations"; "in wording what they want to say quickly enough", "worried about saying something in case they made a mistake in English", "did not know how to say something in English", "did not know the best way to say something in English", "had difficulty with their pronunciation of words", "had difficulty remembering the English equivalent of the word they wanted to say". In other words, they had difficulty in all items. The findings with respect to the difficulties encountered in listening skills indicated that the students had trouble in understanding lengthy descriptions of English, understanding informal English, understanding fast conversations, and understanding conversations in different accents.

Based on these findings, it can be put forward that the students had difficulties in speaking skills most, it was followed by listening, writing and reading skills, respectively. It is possible to come across different problematic subskills in the literature. Among these studies, Boran (1994) indicated that the difficulties in language learning arised from lack of grammar, vocabulary and sentence word order issues. Midoul (2013) found that within speaking, the students were more challenged by presentations, not knowing the best way to express themselves in the target language and to participate in class or group discussions, conferences and seminars, while in writing they were confronted by writing reports/projects, application letters, CVs and emails. According to the study of Diken (2006), students had difficulty in understanding what was spoken and what was listened, and in expressing themselves fluently.

The content analysis of qualitative data gathered from the instructors and the flight attendants indicated that the content of an ESP curriculum for the students of cabin services program should include aviation terminology as aforementioned. In addition to aviation terminology, the long direct quotations indicated that vocabulary with respect to food and drinks, saying prices, dutyfree items, emergency equipment etc. should be included in the ESP curriculum. Their duties and responsibilities were compiled under the theme of "objectives" and they included accepting/refusing/making requests, making explanations, asking/answering questions, making suggestions, giving advice, offering help etc. The difficulties encountered and these duties/responsibilities can be taken as the problematic subskills that the students should improve, so they can be formulated as objectives in an ESP curriculum. 
All of these findings indicated that the students, the instructors and the flight attendants highlighted the necessity of adapting the content of the course in order to respond to the student's specific needs, which is echoed by the conclusions of Alsamadani (2017), Nguyen and Nguyen (2017) and Boran (1994).

Note that all the studies cited above have come up with many suggestions for an ESP curriculum for their target students depending on the needs analysis. To provide some suggestions from literature, Gessesse (2009) suggested communicative activities. Likewise, Nguyen and Nguyen (2017) emphasized the need for more interactive speaking activities in order to maximize students' speaking skills. Lastly, Kaur and Khan (2010) suggested inclusion of specialized vocabulary activities, workplace-based oral presentations, and course materials and topics relevant to students' area of specializations. However, none of these studies have come up with a sample curriculum or at least a guide to exemplify from where to start. As an addition to literature, this study presents the following sample procedures while developing a sample vocational English language curriculum for the students of cabin services program, which was the starting point of this study. Among the many curriculum development models suggested, Hilda Taba's model is suggested to be used while developing an ESP curriculum as it can be managed by the implementers (teachers/instructors) rather than decision makers or administrators. As suggested by Taba (1962), a curriculum should be designed by its users, namely the teachers who are going to implement it.

This study resulted in many noteworthy findings about the components of a curriculum. Now, it is time to put these pieces together. The major steps of her model and the suggestions to be followed for an ESP curriculum based on need analysis are presented below:

1. Diagnosis of needs: In this first step, the teacher (curriculum designer) "identifies the needs of the students for whom the curriculum is being planned" (Ornstein \& Hunkins, 2017, p. 213). This curriculum is planned for the students of cabin services and their needs have been identified as presented above. More concretely, these students need to develop their listening and speaking skills to manage an effective conversation with English-speaking passengers. What is to add, they need to be exposed to authentic content about their future work settings.

2. Formulation of objectives: The teacher specifies the objectives (Ornstein \& Hunkins, 2017) in this step. Before formulating the objectives, the aims and goals of the curriculum should be specified. In this case, a sample aim can be stated as "effective communication in an English-medium context" in a comparatively general fashion. A sample goal, on the other hand, can be formulated as "students will be able communicate in English effectively in an airport context", or "students will develop their listening and speaking skills". This study arrived at some important findings about the necessary language skills with respect to the four language skills, some problematic subskills and the duties the flight attendants pointed while describing their job can. The objectives can be formulated taking these findings into consideration. As this study indicated these students needed to develop their speaking and listening skills and more problematic subskills were found to be related to these skills, therefore the objectives should be based on them. It is advisable to check Bloom's taxonomy of objectives before formulating the objectives. Lots of examples can be listed, but some sample objectives are presented below:

Students will be able to ... "recall the names of emergency equipment, tell the names of dutyfree items, describe foods and drinks, tell the time, interview the passengers, make offers, make requests, respond to the requests, decline requests, make suggestions, give advices, offer help, ask about preferences, make apologizes, ask/answer questions, understand fast conversations, comprehend conversations in different accents".

3. Selection of content: In this step, the content appropriate to help students obtain the above selected objectives is chosen. This indicates that the objectives and content should match (Ornstein \& Hunkins, 2017). Table of specification can be used to show what kind of content will be used for a specific objective. A topical design is suggested. Two samples for content suggestion based on the objectives above are presented below, but the list can continue: 
a. The students can practice the objectives such as describing food and drinks, making offers, and asking about preferences with a content about meal service.

b. The students can practice the objectives such as giving advice, making suggestions and offering help with a content about health problems.

4. Organization of content: In this phase, the teacher organizes the content into a sequence (Ornstein \& Hunkins, 2017). For these students, the content can be sequenced with a chronological sequencing which "reflects the times of real-world occurrences" (Ornstein \& Hunkins, 2017). In this case, the content can be sequenced in a way that reflects the career path of these students and the occurrences encountered before, during and after the flights. To this connection, attention must be paid on the use of authentic and real life texts and tasks.

5. Selection of learning experiences: The teacher selects instructional strategies, methods and techniques to engage the students with the content (Ornstein \& Hunkins, 2017). Sample suggestions are provided below:

a. The content about meal service can be delivered with a video focusing on the details of this process. Then, the students can be asked to share their ideas about the important parts of this process in a speaking activity. Afterwards, they can be assigned with some roles to role-play/act out in similar scenes in groups or pairs. This means that dialogues should be utilized very frequently in order to develop both their listening and speaking skills.

b. The content about health issues can be delivered with a listening text including the experiences of different flight attendants with the passengers having health problems. Following this, the students can be provided with a dialogue to see language patterns, which would be assessed with a true-false activity. They can be asked to discuss the suggestions made by the flight attendants, or they can be given similar cases for which to offer help and give advices. Role-play and drama can be utilized here as well.

6. Organization of learning activities: Based on the content, the teacher organizes the learning activities into a sequence in this step (Ornstein \& Hunkins, 2017) paying attention to the particular students who will be taught. The learning experiences can be organized from simpler activities and receptive skills to achieve to more difficult and productive ones. As seen in the delivery of the content about health issues above, a comparatively simpler listening activity was suggested first and the suggestions ended up with a more difficult activity, role-play.

7. Evaluation and means of evaluation: This is the assessment phase. The curriculum planner determines which objectives have been accomplished (Ornstein \& Hunkins, 2017). In this curriculum, the emphasis should be on the assessment of the objectives regarding speaking and listening skills.

To sum up, this sample of the students needs a learner-centered curriculum led by their specific needs. To this connection, the students should be active throughout the instructional process, so the teacher is expected to be a facilitator who should provide the students as much practice as possible. More concretely, they should be encouraged to speak English as much as possible, but the content should be limited to real life occurrences likely to be experienced in their future work contexts. The procedures described above can be taken as a guide to develop an ESP curriculum depending on the results arrived through needs analysis.

Although this study was planned and undertaken with utmost care, it is not without limitations. Note that this is not a conclusive curriculum and it is open to improvement in terms of more content and objectives. To this connection, future research could utilize observation schedules to further validate these findings.

Acknowledgement. Part of this study was presented orally at International Pegem Conference on Education held in 16-18.09.2020 


\section{References}

Alfehaid, A. F. T. (1994). Developing an ESP curriculum for students of health sciences through needs analysis and course evaluation in Saudi Arabia (Unpublished doctoral dissertation). University of Leicester, UK, Leicester.

Ali, H. I. H., \& Salih, A. R. A. (2013). Perceived views of language teachers on the use of the needs analysis in ESP materials writing. English Language Teaching, 6(3), 11-19. http://dx.doi.org/10.5539/elt.v6n3p11

Alsamadani, H. A. (2017). Needs analysis in ESP context: Saudi engineering students as a case study. Advances in Language and Literary Studies, 8(6), 58-68. http://dx.doi.org/10.7575/aiac.alls.v.8n.6p.58

Arik, S. (2002). An investigation into the requirements of discipline teachers for academic English language use in a Turkish medium university (Unpublished doctoral dissertation), Bilkent University, Ankara.

Ayas, Ö., \& Kırkgöz, Y. (2013). The academic and vocational English language needs of the school of health students. Çukurova University Faculty of Educational Journal, 42(1), 39-55.

Basturkmen, H., \& Lewis, M. (2002). Learners' perspectives of success in an EAP writing course. Assessing Writing, 8, 31-46. https:// doi.org/10.1016/S1075-2935(02)00032-6

Belcher, D. D. (2006). English for specific purposes: teaching to the perceived needs and imagined futures in the world of work, study, and everyday life. TESOL Quarterly, 40, 133-156.

Benesch, S. (1996). Needs analysis and curriculum development in EAP: An example of a critical approach. Testing English to Speakers of Other Language Quarterly, 30(4), 723-738. https:// doi.org/10.2307/3587931

Benesch, S. (1999). Right analysis: Studying power relations in an academic setting. English for Specific Purposes, 18, 313-327. https:// doi.org/10.1016/S0889-4906(98)00011-8

Berman, R., \& Cheng, L. (2001). English academic language skills: Perceived difficulties by undergraduate and graduate students, and their academic achievement. Canadian Journal of Applied Linguistics, 4(1-2), 2540.

Boran, G. (1994). A needs analysis for ESP classes at the Tourism Education Department of the Trade Business and Tourism Education Faculty of Gazi University (Unpublished master's thesis). Bilkent University, Ankara.

Brindley, G. (1989). The role of needs analysis in adult ESL program design. In R. K. Johnson. (Eds.), The second language curriculum (pp.63-78). Cambridge University Press.

Brown, J. D. (1995). The elements of language curriculum: A systematic approach to program development. Heinle \& Heinle/Cambridge University Press.

Buyukyavuz, O. (2006). Teaching foreign language (English) for specific purpose applying needs analysis (the case of S.D.U. Egirdir vocational school) (Unpublished master's thesis). Suleyman Demirel University, Isparta.

Casanave, C., \& Hubbard, P. (1992). The writing assignments and writing problems of doctoral students: Faculty perceptions, pedagogical issues, and needed research. English for Specific Purposes, 11(1), 33-49. https:/ / doi.org/10.1016/0889-4906(92)90005-U

Chen, Y. (2006). From the common core to specific. Asian ESP Journal, 1(3), 24-50.

Chia, H.-U., Johnson, R., Chia, H. L., \& Olive, F. (1999). English for college students in Taiwan: A study of perceptions of English needs in a medical context. English for Specific Purposes, 18(2), 107-119. https://doi.org/10.1016/S0889-4906(97)00052-5

Clement, A., \& Murugavel, T. (2015). English for employability: A case study of the English language training needs of engineering students in India. English Language Teaching, 8(2), 116-125. https://doi.org/10.5539/elt.v8n2p116

Cohen, L., Manion, L., \& Morrison, K. (2007). Research methods in education. Taylor and Francis Group.

Creswell, J. W. (2009). Research design: Qualitative, quantitative, and mixed methods approaches. (3 ${ }^{\text {rd }}$ Ed.). Sage Publications.

Cutting, J. (2011) English for airport ground staff. English for Specific Purposes, 31, 3-13. https://doi.org/10.1016/j.esp.2011.06.002

Derado, S. D. (2015). Fostering cross-cultural communicative competence in business English classes through literary short stories. ESP Today, 3(1), 99-119.

Diken, Ü. (2006). Teaching foreign language (English) for specific language purpose applying need analysis (the case study of S.D.U. Eğirdir Vocational High School) (Unpublished master's thesis). Süleyman Demirel University, Turkey.

Dudley-Evans, T., \& St. John, M. J. (1998). Developments in ESP: A multi-disciplinary approach. Cambridge University Press.

Evans, S., \& Green, C. (2007). Why EAP is necessary: A survey of Hong Kong tertiary students. Journal of English for Academic Purposes, 6, 3-17. https:// doi.org/10.1016/j.jeap.2006.11.005 
Evans, S., \& Morrison, B. (2011a). Meeting the challenges of English-medium higher education: The first-year experiences in Hong Kong. English for Specific Purposes, 30, 198-208. https://doi.org/10.1016/j.esp.2011.01.001

Evans, S., \& Morrison, B. (2011b). The first term at university: Implications for EAP. ELT Journal, 65(4), 387397. https://doi.org/10.1093/elt/ccq072

Ferris, D. (1998). Students' views of academic aural/oral skills: A comparative needs analysis. TESOL Quarterly, 32, 289-318. https://doi.org/10.2307/3587585

Flowerdew, J., \& Miller, L. (1992). Student perceptions, problems and strategies in second language lecture comprehension. RELC Journal, 23, 60-80.

Fox, J., \& Artemeva, N. (2017). From diagnosis toward academic support: Developing a disciplinary ESPbased writing task and rubric to identify the needs of entering undergraduate engineering students. ESP Today, 5(2), 148-171.

Fraenkel, J. R, Hyun, H.H., \& Wallen, N. E. (2012). How to design and evaluate research in education (8th Ed.). McGraw Hill

Gall, M. D., Gall, J. P., \& Borg, W. W. (2003). Educational research: an introduction. Pearson Education Inc.

Gessesse, M. (2009). Identifying students' language needs in private medical colleges in Bair Dar (Unpublished master's thesis). Bahir Dar University, Ethiopia.

Gokce, A., \& Batman, O. (2015). Needs assessment of English for occupational purposes (EOP) education in tourism associate degree programs based on students' opinions. PARADOKS Economics, Sociology and Policy Journal, Special Issue 1, 211-264.

Hutchinson, T., \& Waters, A. (1987). English for specific purposes: A learning-centered approach. Cambridge University Press.

Hyland, K. (1997). Is EAP necessary? A survey of Hong Kong undergraduates. Asian Journal of English Language Teaching, 7, 77-99.

Ivanic, R. (2006). Language, learning and identification. In R. Kiely, P. Rea- Dickins, H.Woodfield, \& G. Clibbon (Eds.), Language, culture and identity in applied linguistics (pp. 7-29). British Association for Applied Linguistics.

Jenkins, S., Jordan, M., \& Weiland, P. (1993). The role of writing in graduate engineering education: A survey of faculty beliefs and practices. English for Specific Purposes, 12(1), 51-67. https://doi.org/10.1016/08894906(93)90027-L

Johns, A. M. (1981). Necessary English: A faculty survey. TESOL Quarterly, 15(1), 5157. https://doi.org/10.2307/3586373

Jones, G. (1990). ESP textbooks: Do they really exist? English for Specific Purposes, 9, 89-93. https://doi.org/10.1016/0889-4906(90)90030-G

Kaewpet, C. (2009). A framework for investigating learner needs: Needs analysis extended to curriculum development. Electronic Journal of Foreign Language Teaching, 6(2), 209-220.

Kaur. S., \& Clarke, C. M. (2009). Analyzing the English language needs of human resource staff in multinational companies. ESP World, 3(24), 2009.

Kaur, S. \& Khan, A. B. M. A. (2010). Language needs analysis of art and design students: Considerations for ESP course design. ESP World, 2(28), 1-15.

Kikuchi, K. (2005). Student and teacher perceptions of learning needs: a cross analysis. Shiken: JALT Testing $\mathcal{E}$ Evaluation SIG Newsletter, 9(2), 8-20.

Lee, C. Y. (1998). English for nursing purposes: A needs assessment for professional-oriented curriculum design. Academic Journal of Kang-Ning, 1(1). 55-72.

Leki, I., \& Carson, J. (1994). Students' perceptions of EAP writing instruction and writing needs across the disciplines. TESOL Quarterly, 28(1), 285-296. https:// doi.org/10.2307/3587199

Mazdayasna, G., \& Tahririan, M.H. (2008) Developing a profile of the ESP needs of Iranian students: The case of students of nursing and midwifery. Journal of English for Academic Purposes, 7(4), 277-289. https://doi.org/10.1016/j.jeap.2008.10.008

Midoul, M. (2013). Needs analysis of engineering students at ENSAM (Unpublished master's thesis). Moulay Ismail University, Morocco.

Moder, C. L. (2013). Aviation English. In B. Paltridge and S. Starfield (Eds.). The handbook of English for specific purposes, (227-242). Blackwell Publishing.

Moslemi, F., Moinzadeh, A., \& Dabaghi, A. (2011). ESP needs analysis of Iranian MA students: A case study of the university of Isfahan. English Language Teaching, 4(4), 121-129. http://dx.doi.org/10.5539/elt.v4n4p121 
Moyo, J. \& Mann, C. C. (2018). Face validity in ESP: A quantitative student validation of an engineering ESP approach. ESP Today, 6(2), 228-253. https://doi.org/10.18485/esptoday.2018.6.2.5

Nguyen, H., \& Nguyen, T. (2017). English for specific purposes (ESP): Perceptions of students and teachers of learning needs at a Vietnamese school. International Journal of Advanced Research, 5(4), 793-803. http://dx.doi.org/10.21474/IJAR01/3877

Nunan, D. (1988). The learner-centred curriculum: A study in second language teaching. Cambridge University Press.

Ornstein, A. C., \& Hunkins, F. P. (2017). Curriculum: Foundations, principles and issues (7th ed.). Pearson Education Limited.

Richards, J. C. (2001). Curriculum development in language education. Cambridge University Press.

Sullivan, P., \& Girginer, H. (2002). The use of discourse analysis to enhance ESP teacher knowledge: An example of Aviation English. English for Specific Purposes, 21, 397-404. https://doi.org/10.1016/S08894906(01)00042-4

Taba, H. (1962). Curriculum development: Theory and practice. New York: Harcourt Brace.

Taillefer, G. F. (2007). The professional language needs of economics graduates: assessment and perspectives in the French context. English for Specific Purposes, 26(2), 135-155. https://doi.org/10.1016/j.esp.2006.06.003

Tasci, C. (2007). An analysis of medical students' English language needs (Unpublished master's thesis). University of Bilkent. Ankara.

Ulla, M. B., \& Winitkun, D. (2017). Thai learners' linguistic needs and language skills: Implications for curriculum development. International Journal of Instruction, 10(4), 203-220. https:// doi.org/10.12973/iji.2017.10412a

Wang, A. (2006). Teaching Aviation English in the Chinese context: Developing ESP theory in a non-English speaking country. English for Specific Purposes, 26(1), 121-128. https:// doi.org/10.1016/j.esp.2005.09.003

Xiao, L. (2006). What can we learn from a learning needs analysis of Chinese English majors in a university context? Asian EFL Journal, 8(4), 74-99. 